\title{
PARTICIPATION IN COMPETITIVE SPORT AND SPORT LEISURE AMONG WORKING INHABITANTS OF WARSAW BASED ON SELECTED GROUPS
} Participation in competitive sport and sport leisure

\author{
ELŻBIETA BIERNAT ${ }^{1}$, MAŁGORZATA TYBURCY ${ }^{2}$, ANTONI K. GAJEWSKI ${ }^{2}$ \\ 1 Warsaw School of Economics, Physical Education and Sport Centre \\ 2 The Josef Pilsudski University of Physical Education in Warsaw
}

Mailing address: Elżbieta Biernat, Warsaw School of Economics, 162 Niepodległości Avenue,
02-554 Warszawa, tel.: +48 22 6653839, fax: +48 22 8495312, e-mail: elzbieta.biernat@sgh.waw.pl

\begin{abstract}
Introduction. The aim of this work was to explore sports activities among various socio-professional groups based on the example of the inhabitants of Warsaw. Material and methods. The sample comprised of 6547 inhabitants of Warsaw - representatives of 16 professional groups. The study was conducted with the use of an especially designed questionnaire, featuring two sections - the first one devoted to organised sport, and the second and on the participation in sport leisure (regular, periodical, sporadic) within the previous year. In keeping with the European definition, sport is understood as both competitive sport, and regular sport leisure or recreation. The survey was carried out by trained interviewers exclusively in March and November 2006-2008. Results. Participation in sport activities among Poles increased not only compared to other European countries, but also to previous Polish studies, as it pertained to $43 \%$ of Warsaw inhabitants. The proportion of Warsaw residents involved in organised sport amounted to $6 \%$, and those involved in regular recreation to $41 \%$. Pupils and students are the most active both in sport and in leisure. Nearly $19 \%$ of pupils and nearly $8 \%$ of students are involved in organised sport activities, while for sport leisure this proportion amounts to 55\% and 50\% respectively. In the case of both competitive sport activities and leisure the number of men exceeds the number of women involved in them. Conclusions. Sport activities that Poles involve in are still not close to the recommended WHO and ATMS norms.
\end{abstract}

Key words: sport, professional groups, Warsaw

\section{Introduction}

Sport and physical recreation have been subject to intense scientific research, particularly in the context of prophylaxis and health promotion $[1,2,3,4,5,6,7]$. Nevertheless, different understanding of notions utilised poses difficulties in both conducting reliable research and interpreting their findings $[8,9,10]$.

The definitions utilised in Poland pertain solely to individuals involved in competitive sport activities [11], which means that they belong to a sport club and participate in competitions. At the same time, the participation in sport activities is understood entirely differently in the old EU countries, as there the statistics include both individuals practicing organised sport and those who are involved in various sports disciplines during their free time [12, 13]. In the latest of cases it is not obvious which disciplines should be considered sports disciplines, e.g. whether snooker or darts can be included among them. As a result of the difference in the above definitions, the Polish statistics indicate that only $9-21 \%$ of Poles practice sports [CBOS $2003-9.0 \%$ regularly, $12 \%$ relatively frequently, $21 \%$ occasionally] or $28.2 \%$ [GUS 2000 - sporadically or occasionally], while sufficient physical activity pertains only to $3-10 \%$ of Poles depending on the age group [14], which presents our country in rather unfavourable light in the context of physical activity compared to other nations. Sport with some regularity (3-4 and 1-2 times a week) is practiced by $31 \%$ of the citizens of the EU member countries [13]. Regular participation in organised, competitive sport is declared by $2-10 \%$ of Europeans, and in sport leisure by $6-29 \%$ of them [12].

The following paper explores sport activity of various socio-professional groups, based on the example of the inhabitants of Warsaw. 


\section{Material and methods}

\section{Sample}

The study was carried out among 6547 inhabitants of Warsaw. The base for analyses was a group of 6541 respondents (38.5\% of men and $61.5 \%$ of women) aged $\leq 19$ (15.9\%), 20-29 (30.9\%), 30-39 (19.1\%), 40-49 (15.2\%), 50-59 $(14.3 \%)$ and $\geq 60(4.7 \%)$, which results from the screening assumptions of the survey. Nevertheless, due to the fact that not all the individuals answered all questions asked, the number of individuals included in particular analyses might slightly differ from the above base.

\section{Organization of the research and sampling}

The sample comprised of the representatives of 14 socio-professional groups, namely teachers (university, high school, junior high school, and primary school), research workers at research institutes, healthcare professionals, bank employees, civil servants, representatives of local administration, administrative and technical staff (at universities, hospitals, research institutes and theatres), retail workers, hypermarket employees and actors. In addition to the professional groups, there were also students (II and IV year) and pupils (last grade of high school and last grade of junior high school) examined.

\section{Selection of the sample}

It was assumed in the research, that each professional group will comprise of about 300 people. An exception was made for the group of students, which was to include 500600 people, because of the high percentage of students in the population of Warsaw.

There was a two-stage draw used. The first stage consisted on drawing the institutions employing 3-10 individuals, practicing a particular job, of all the institutions this kind in Warsaw. The exception was the group of the retail workers. In this particular case there were three streets selected in each district, on which a large number of commercial building was located.

The second stage consisted of drawing the defined number of individuals in each institution. Thus, in the institutions employing up to 35 employees the research covered all the individuals. In the institutions employing or educating a higher number of people there was a $30 \%$ sample (but not more than 100 people) selected.

Slightly different procedures were applied to the pupils and the retail workers. In the first case, in each school there was one class of each grade randomly selected and all the students present on the particular day at school were examined. In the second case, the 10 institutions at each randomly selected street were drawn and all the employees and owners of the store, but no more than 3 people, were examined.

For the profile of the sample see Table 1.

Table 1. Sample profile

\begin{tabular}{|c|c|c|c|c|c|c|c|}
\hline & \multirow{3}{*}{ Sample profile } & \multicolumn{6}{|c|}{ Number and proportion of individuals } \\
\hline & & \multicolumn{2}{|c|}{ Males } & \multicolumn{2}{|c|}{ Females } & \multicolumn{2}{|c|}{ Total } \\
\hline & & $\mathrm{n}$ & $\%$ & $\mathrm{n}$ & $\%$ & $\mathrm{n}$ & $\%$ \\
\hline & & \multicolumn{2}{|c|}{$(n=2515)$} & \multicolumn{2}{|c|}{$(n=4003)$} & \multicolumn{2}{|c|}{$(\mathrm{n}=6518)$} \\
\hline \multirow{7}{*}{ Age } & $\leq 19$ & 473 & 18.8 & 562 & 14.0 & 1035 & 15.9 \\
\hline & $20-29$ & 821 & 32.6 & 1191 & 29.8 & 2012 & 30.9 \\
\hline & $30-39$ & 459 & 18.3 & 787 & 19.7 & 1246 & 19.1 \\
\hline & $40-49$ & 304 & 12.1 & 685 & 17.1 & 989 & 15.2 \\
\hline & $50-59$ & 298 & 11.8 & 633 & 15.8 & 931 & 14.3 \\
\hline & $\geq 60$ & 160 & 6.4 & 145 & 3.6 & 305 & 4.7 \\
\hline & & \multicolumn{2}{|c|}{$(n=2513)$} & \multicolumn{2}{|c|}{$(n=3998)$} & \multicolumn{2}{|c|}{$(n=6511)$} \\
\hline \multirow{3}{*}{ Marital status } & In a relation & 1043 & 41.5 & 1858 & 46.5 & 2901 & 44.6 \\
\hline & Single & 1439 & 57.3 & 1990 & 49.8 & 3429 & 52.7 \\
\hline & Divorced/ widow/er & 31 & 1.2 & 150 & 3.8 & 181 & 2.8 \\
\hline & & \multicolumn{2}{|c|}{$(\mathrm{n}=2519)$} & \multicolumn{2}{|c|}{$(n=4022)$} & \multicolumn{2}{|c|}{$(n=6541)$} \\
\hline \multirow{5}{*}{ Education } & Higher & 1416 & 56.2 & 2285 & 56.8 & 3701 & 56.6 \\
\hline & Secondary & 542 & 21.5 & 1073 & 26.7 & 1615 & 24.7 \\
\hline & Vocational & 69 & 2.7 & 85 & 2.1 & 154 & 2.4 \\
\hline & Primary/Pupil & 492 & 19.5 & 579 & 14.4 & 1071 & 16.3 \\
\hline & & \multicolumn{2}{|c|}{$(n=2502)$} & \multicolumn{2}{|c|}{$(n=3932)$} & \multicolumn{2}{|c|}{$(n=6434)$} \\
\hline \multirow{3}{*}{ Body Mass Index } & Underweight $(<20)$ & 21 & 0.8 & 187 & 4.8 & 208 & 3.2 \\
\hline & Norm $\quad(20.0-24.9)$ & 1471 & 58.8 & 2967 & 75.5 & 4438 & 69.0 \\
\hline & Overweight $(25.0-29.9)$ & 1010 & 40.4 & 778 & 19.8 & 1788 & 27.8 \\
\hline
\end{tabular}


The vast majority of the respondents, both adults and individuals aged under 18 have correct proportion of the weight to height. Due to minimal size of extreme categories, this variable was categorised according to three values: underweight, norm, overweight. The value of the variable, as well as the inclusion in particular categories were calculated based on the Szczeklik's classification [17]. The BMI categorisation for individuals aged under 18 was carried out based on the BMI classification for children and youths according to the Cole's index [18].

The distribution of demographic variables (gender, age, education) in the sample considerably differs from the distribution of these variables in the population, even when it is defined exclusively as the population of Warsaw inhabitants. Overrepresented are females (due to the group of teachers of high schools, junior highs and primary schools), and young individuals aged up to 30 (because of the students and pupils examined) over half of the respondents are university graduates (examined were the groups to which the international scale of social prestige and economic status of the profession attribute the highest positions). This fact means that the analysis results can be extrapolated to the population defined as the sum of representatives of professional categories the representatives of which were include in the sample. Thus, it can be assumed that the sample is largely representative of the population of working inhabitants of Warsaw, from the selected professional groups and excluding the blue collar workers, students and pupils.

\section{Collecting the surveys}

The study was conducted exclusively in March and November (starting in March 2006 and ending in March 2008), taking into account the approximate mean temperatures and rainfall in those months, as well as the fact that it was not the period of increased physical activity (e.g. summer or winter holidays, etc.). Hence, the measured sport activity can be considered habitual.

The interviews were carried out by 28 trained interviewers at the respondents' place of work or education, plus in emergency situations additionally by 2 individuals representing the managerial staff of the research project. Each interviewer conducted an average of 240 surveys.

In the case of the majority of groups the refusal rate was low, ranging between 3 and 5\%. A slightly larger number of refusals was observed for retail employees (ca. 10\%) and actors (ca. 20\%).

\section{Terms utilised}

The following paper presents the research results pertaining to the participation of Warsaw inhabitants in competitive sport, regular sport leisure and sport for all within the previous year.

Competitive sport was understood as practicing a given sports discipline in an organised manner. The prerequisite for such a classification was the membership in a sports club and participation in training sessions and competitions.

Regular sport leisure was defined as practicing a selected sports discipline or exercising (e.g. jogging, biking, swimming, gymnastics, etc.) recreationally (voluntarily, for one's own pleasure, during free time, after having performed all the duties), at least once a week for 5 months a year. Sport for all was understood as both involvement in organised sport, and regular participation in sport leisure.

\section{Research tool}

The research tool was a questionnaire - prepared and modified after the pilot project. The participants were asked about the type and frequency of practiced sports disciplines and recreational activities.

\section{Statistical analysis}

The study results were entered into the SPSS 17 software and presented in tables, in the form of appropriate figures and fractions. The chi-square logarithmic function was utilised in the statistical analysis [19].

\section{Results}

\section{Participation in competitive sport}

Competitive sport was practiced within the previous year by a small proportion of Warsaw inhabitants surveyed (Tab. 2). Men were involved in this type of activity more often than women were. Among all socio-professional groups interviewed, organised sport was practiced the most often by young individuals - pupils in the last grade of junior high school and in the last grade high school, as well senior students and sophomores.

The frequency analysis cannot be conducted for the entire table due to the fact that over $20 \%$ of cells in the table have the expected size of under 5 . It is also not possible to compare men and women in all the groups, since the newly created group (a combination of all sub-samples) shall not be a sample of any actual population. At the same time, it is justified to point to differences in the declared frequency of participation in sport between females and males in particular groups. Among healthcare professionals, junior high school teachers, sophomores, pupils in the last grade of high school and junior high school, as well as administrative staff men considerably more often than women $(p<0.05)$ involved in organised sport activities.

It also seems justified to combine the sub-samples of teachers from various types of schools, i.e. high schools, junior high schools, and primary schools, as well as commerce representatives, i.e. retail and hypermarket employees. As a result of the analysis for the entire teacher subsample (excluding university teachers) no major differences in the frequency of participation in organised sport between males and females were observed. Nevertheless, such a correlation was noticed for commerce representatives, as men practiced organised sport considerably more often than women did $(\mathrm{p}<0.05)$. 
Table 2. Number and proportion of individuals practicing sports

\begin{tabular}{|c|c|c|c|c|c|c|c|}
\hline \multirow{2}{*}{ Socio-professional groups } & & \multicolumn{2}{|c|}{$\begin{array}{c}\text { Organised } \\
\text { (competitive) sport }\end{array}$} & \multicolumn{2}{|c|}{ Regular sport leisure } & \multirow{2}{*}{\multicolumn{2}{|c|}{ Sport }} \\
\hline & & $\mathrm{n}$ & $\%$ & $\mathrm{n}$ & $\%$ & & \\
\hline \multirow{3}{*}{$\begin{array}{l}\text { Healthcare } \\
\text { professional }\end{array}$} & Men & 27 & $11.3^{a}$ & 91 & $37.9^{a}$ & 100 & $41.7^{a}$ \\
\hline & Women & 16 & 3.1 & 118 & 22.5 & 127 & 24.2 \\
\hline & Total & 43 & 5.6 & 209 & 27.4 & 227 & 29.7 \\
\hline \multirow{3}{*}{ University teachers } & Men & 6 & 2.3 & 137 & 52.7 & 138 & 54.1 \\
\hline & Women & 2 & 1.0 & 92 & 45.5 & 93 & 46.5 \\
\hline & Total & 8 & 1.7 & 229 & 49.6 & 231 & 50.8 \\
\hline \multirow{3}{*}{ High school teachers } & Men & 1 & 1.1 & 37 & 42.5 & 37 & 42.5 \\
\hline & Women & 5 & 1.9 & 91 & 35.4 & 93 & 36.2 \\
\hline & Total & 6 & 1.7 & 128 & 37.2 & 130 & 37.8 \\
\hline \multirow{3}{*}{$\begin{array}{l}\text { Junior high } \\
\text { school teachers }\end{array}$} & Men & 8 & $10.5^{a}$ & 50 & $65.8^{b}$ & 53 & $69.7^{a}$ \\
\hline & Women & 5 & 1.7 & 127 & 43.1 & 130 & 44.1 \\
\hline & Total & 13 & 3.5 & 177 & 47.7 & 183 & 49.3 \\
\hline \multirow{3}{*}{$\begin{array}{l}\text { Primary } \\
\text { school teachers }\end{array}$} & Men & 2 & 4.8 & 23 & $54.8^{a}$ & 24 & $57.1^{\mathrm{a}}$ \\
\hline & Women & 5 & 1.5 & 128 & 38.6 & 131 & 39.5 \\
\hline & Total & 7 & 1.9 & 151 & 40.4 & 155 & 41.4 \\
\hline \multirow{3}{*}{$\begin{array}{l}\text { Sophomores } \\
\text { students }\end{array}$} & Men & 28 & $12.3^{a}$ & 142 & 62.3 & 153 & 67.1 \\
\hline & Women & 12 & 4.5 & 174 & 64.7 & 183 & 68.0 \\
\hline & \begin{tabular}{|l|} 
Total \\
\end{tabular} & 40 & 8.0 & 316 & 63.6 & 336 & 67.6 \\
\hline \multirow{3}{*}{$\begin{array}{l}\text { First year students } \\
\text { of the two-year BA course }\end{array}$} & Men & 22 & 7.8 & 116 & 41.0 & 127 & 44.9 \\
\hline & Women & 27 & 8.4 & 147 & 45.9 & 160 & 50.0 \\
\hline & Total & 49 & 8.1 & 263 & 43.6 & 287 & 47.6 \\
\hline \multirow{3}{*}{ Last grade of high school pupils } & \begin{tabular}{|l|} 
Men \\
\end{tabular} & 41 & $17.5^{a}$ & 147 & $62.8^{b}$ & 160 & $68.4^{a}$ \\
\hline & Women & 29 & 10.5 & 109 & 39.4 & 124 & 44.8 \\
\hline & Total & 70 & 13.7 & 256 & 50.1 & 284 & 55.6 \\
\hline \multirow{3}{*}{ Last grade of junior high school pupils } & Men & 72 & $29.5^{a}$ & 152 & 62.3 & 179 & $73.4^{a}$ \\
\hline & Women & 51 & 17.8 & 169 & 58.9 & 182 & 63.4 \\
\hline & Total & 123 & 23.2 & 321 & 60.5 & 361 & 68.0 \\
\hline \multirow{3}{*}{ Civil servants } & Men & - & - & 48 & $55.8^{a}$ & 48 & $55.8^{a}$ \\
\hline & Women & 1 & 0.5 & 75 & 35.0 & 76 & 35.5 \\
\hline & Total & 1 & 0.3 & 123 & 41.0 & 124 & 41.3 \\
\hline \multirow{3}{*}{$\begin{array}{l}\text { Representatives } \\
\text { of local administration }\end{array}$} & Men & 3 & 2.5 & 42 & 34.4 & 42 & 34.4 \\
\hline & Women & 2 & 1.0 & 59 & 28.8 & 59 & 28.8 \\
\hline & \begin{tabular}{|l|} 
Total \\
\end{tabular} & 5 & 1.5 & 101 & 30.9 & 101 & 30.9 \\
\hline \multirow{3}{*}{$\begin{array}{l}\text { Research workers } \\
\text { at research institutes }\end{array}$} & Men & 3 & 2.2 & 49 & $35.8^{a}$ & 52 & $38.0^{a}$ \\
\hline & Women & 2 & 1.2 & 41 & 25.0 & 43 & 26.2 \\
\hline & \begin{tabular}{|l|} 
Total \\
\end{tabular} & 5 & 1.7 & 90 & 29.9 & 95 & 31.6 \\
\hline \multirow{3}{*}{ Actors } & Men & 6 & 9.0 & 35 & 52.2 & 37 & 55.2 \\
\hline & \begin{tabular}{|l|} 
Women \\
\end{tabular} & - & - & 16 & 43.2 & 16 & 43.2 \\
\hline & Total & 6 & 5.8 & 51 & 49.0 & 53 & 51.0 \\
\hline \multirow{3}{*}{ Retail workers } & Men & 5 & 2.9 & 59 & $34.5^{b}$ & 60 & $35.1^{\mathrm{a}}$ \\
\hline & Women & 1 & 0.5 & 29 & 14.4 & 29 & 14.4 \\
\hline & Total & 6 & 1.6 & 88 & 23.7 & 89 & 23.9 \\
\hline \multirow{3}{*}{$\begin{array}{l}\text { Hypermarket } \\
\text { employees }\end{array}$} & Men & 5 & 3.9 & 22 & 17.1 & 24 & 18.6 \\
\hline & Women & 2 & 1.1 & 23 & 12.5 & 23 & 12.5 \\
\hline & Total & 7 & 2.2 & 45 & 14.4 & 47 & 15.0 \\
\hline & Men & 3 & $2.6^{a}$ & 42 & 36.2 & 45 & 38.8 \\
\hline Administrative and technical staff & Women & - & - & 76 & 29.6 & 76 & 29.6 \\
\hline & Total & 3 & 0.8 & 118 & 31.6 & 121 & 32.4 \\
\hline Total & & 392 & 6.0 & 2666 & 40.8 & 2824 & 43.2 \\
\hline
\end{tabular}




\section{Participation in regular sport leisure}

Individuals involved in sport leisure are defined first of all as those who do it regularly (Tab. 2). Sporadic (occasional) participation cannot reflect the participation in sport leisure in general, neither can periodical involvement in sport, which reflects holiday activity. Since $41 \%$ of the respondents ( $47 \%$ of men and $36 \%$ of women) participated in this type of activity regularly, the actual number of individuals involved in leisure is lower. The highest proportion of individuals regularly involved in physical exercise can be observed among sophomores and pupils in the last grade of junior high school, as well as those in the last grade of high school, university teachers, and actors. At the same time, it is the lowest among commerce employees and healthcare professionals. The results indicate that as many as $86 \%$ hypermarket employees, $76 \%$ retail employees, and $73 \%$ of healthcare personnel did not practice any sport discipline or physical exercise within the previous year. The results were similar for researchers at research institutes, local administration personnel and high school teachers.

The frequency analysis revealed differences between males and females (in particular groups) in regular involvement in sport leisure, as men representing healthcare, civil service employees, researchers at research institutes, and primary school teachers considerably more often. A $(p<0.05)$ than women representing these groups were involved in regular sport leisure within the previous year. The same correlation was observed for retail employees, junior high school teachers, and pupils in the last grade of high school $(\mathrm{p}<0.001)$.

The combination of teacher sub-samples from various types of schools (high schools, junior high schools and primary schools) and commerce employees (retail and hypermarket workers) indicates that both male teachers and male commerce employees considerably more often $(p<0.001)$ involves in regular sport leisure than women representing the above groups did. Similar differences were noticed for officials (local administration and civil servants), yet at the significance level of $\mathrm{p}<0.01$.

The analysis of participation in regular sport leisure among men (in the total sample) revealed considerable differences $(p<0.001)$ between men in particular groups (Fig $1)$.

Among all men participating in the study junior high school teachers, pupils in the last grade of high school, pupils in the last grade of junior high school, and sophomores regularly participated in sport leisure (more often than others). For the significance level see Figure 1.

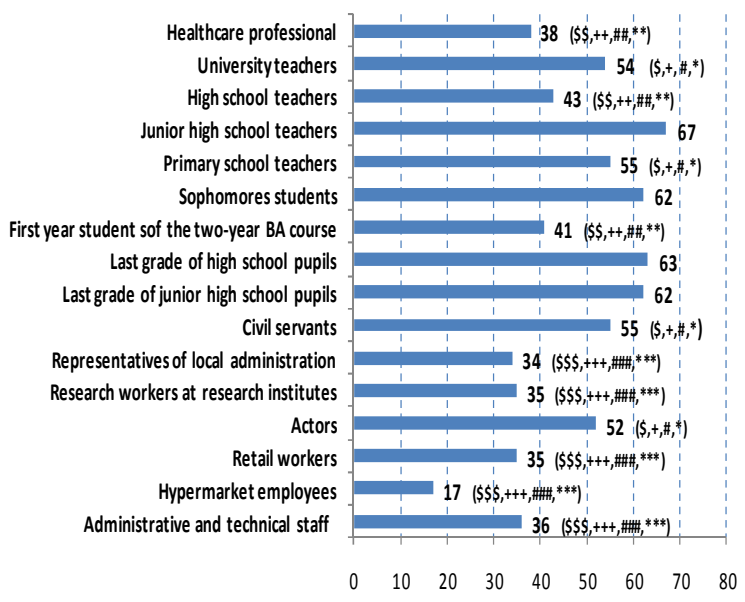

$\$$ - significantly different from junior high school teachers at significance level of $\$-p<0.05 ; \$ \$-p<0.01 ; \$ \$ \$ p<0.001$

+- significantly different from sophomores students at significance level of $^{+}-\mathrm{p}<0.05 ;^{++}-\mathrm{p}<0,01 ;^{+++}-\mathrm{p}<0.001$

$\#$ - significantly different from last grade of high school pupils at signifi-

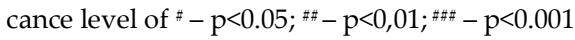

* - significantly different from last grade of junior high school pupils at significance level of * $-p<0.05 ;{ }^{* *}-p<0,01 ; * *-p<0.001$

Figure 1. Regular participation in sport leisure among men

The same correlation was revealed for females (Fig. 2). Among all women sophomores and pupils of the last junior high school regularly involved in sport leisure considerably more often than other groups did.

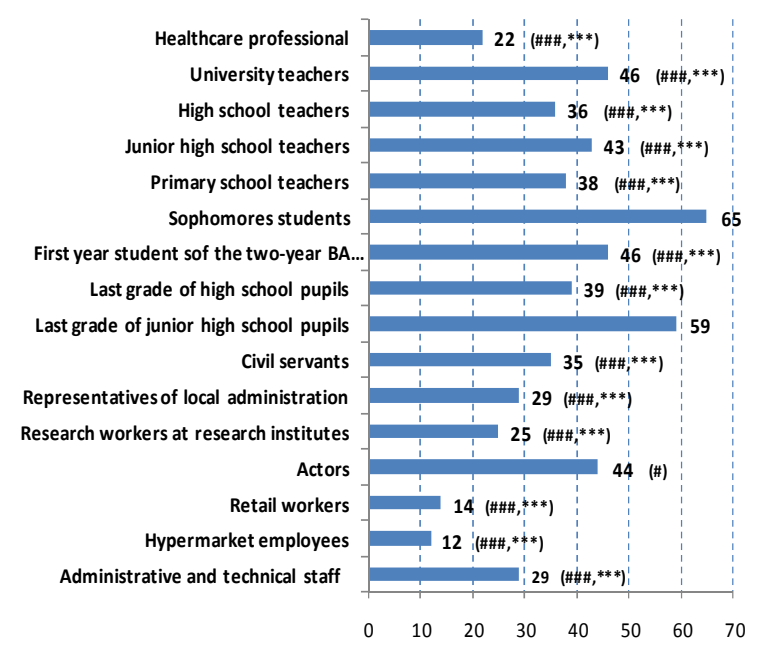

\# - significantly different from sophomores at significance level of \# $\mathrm{p}<0.05 ; \#$; $\mathrm{p}<0.001$

* - significantly different from pupils in the last grade of junior high school *** $-\mathrm{p}<0.001$

Figure 2. Regular participation in sport leisure among women 


\section{Participation in sport for all}

Participation in sport for all pertained both to practicing any discipline in an organised manner, and regular involvement in sport leisure. $43 \%$ of Warsaw inhabitants surveyed the participated in sport defined in such a manner (Tab. 2). In the majority of cases these were young individuals: sophomores, pupils in the last grade of junior high school and of high school, as well as university teachers, and actors. Among all the groups included in the study, sport activities were taken up the least often by hypermarket employees $(15 \%)$ and retail workers $(24 \%)$, as well as healthcare professionals (30\%).

In nearly every group surveyed (healthcare, civil servants, retail, junior high school and primary school teachers, pupils in the last grade of junior high school or high school, researchers at research institutes) men considerably more often $(\mathrm{p}<0.05)$ than women were involved in sport activity.

\section{Discussion}

In the contemporary world one notion of 'sport' is utilised to define physical activity of both individuals and groups, organised in various forms, and for various purposes. The differences in understanding it all over the world make it impossible to compare research findings, and lead to misinterpretation of their results. The existing study results indicate that Poland lags behind other countries as regards its participation in sport. Hence, the following work defines sport - according to European classification - as an area including both competitive sport and sport leisure. What also needs to be stressed is that only regular participation in leisure was taken into account, due to the fact that the measured activity needs to be referred to as habitual.

The research results indicate that $43 \%$ of Warsaw inhabitants participate in sport for all activities, which is closer to scores attained by two Scandinavian nations considered the most active in this respect, namely Swedes $(59 \%)$ and Finns (73\%), $12 \%$ and $6 \%$ of whom respectively participate in intense organised competitive sport, $25 \%$ and $33 \%$ in intense, $5 \%$ and $5 \%$ in regular, organised and competitive, and $17 \%$ and $29 \%$ respectively in regular sport leisure [12]. At the same time, Poland outdistance other countries included in COMPASS studies, namely the Netherlands $(32 \%)$, Ireland $(28 \%)$, the UK $(28 \%)$, Spain $(15 \%)$, Italy $(10 \%)$ and the citizens of the EU member countries, from which sport with some regularity (3-4 and 1-2 times a week) is practiced by $31 \%$ of the examined individuals [13]. Nevertheless, one has to bear in mind the fact that the Warsaw sample comprised of well-educated individuals (57\%). Sport is practiced the most often by university teachers (51\%) and actors $(51 \%)$, as well as young individuals: sophomores (68\%), pupils in the last grade of junior high school (68\%) and high school (56\%). Out of all groups included in the study, hypermarket $(15 \%)$ and retail employ- ees $(24 \%)$, as well as - which is rather alarming - healthcare professionals $(30 \%)$ involve in sport activities the least often.

The study results indicate that the participation in sport among Poles increased not only in comparison to other European countries, but also to previous Polish research. And so the proportion of Warsaw residents practicing sport is considerably higher $(6 \%)$, than the proportion of Poles with higher education declaring this type of activity (2\%) surveyed by Bywalec [20] and 25 year olds (16\%), 35 year olds and 50 year olds (over $7 \%$ and over $4 \%$ respectively) questioned by Charzewski [21]. Involvement in organised sport was less often declared by the study subjects than by Warsaw court police officers (11\%) [22]. Nevertheless, given the profile of policemen's work, this fact should come as no surprise.

The declarations of participation in sport leisure $(80 \%)$ were also comparable to, among others, Warsaw policemen (81\%); [22] and physical education teachers from urban locations in lubuskie and zachodniopomorskie provinces (over $80 \%$ ) [23]. At the same time, this proportion was higher than among females surveyed by Salita [24]; (62\% aged $20-30,30 \%$ aged 50-60), Polish financial elites questioned by Alejziak [25] (40\%, 43\% respectively) and Poles surveyed by Charzewski ( $17 \%$ of males and $10 \%$ of females). What needs to be stressed is that the differences might result from the timing of the study, and methodological variance, and differences in the level of education among study subjects.

Individuals involved in sport leisure are defined as those who do it regularly. As $40.8 \%$ of all the respondents claimed to involve in sport leisure on a regular basis, the actual number of individuals participating in this type of activity is lower. Also in this case the highest proportion of individuals regularly involved in physical activity was observed among young individuals (ca. $60 \%$ ), as well as university teachers $(50 \%)$ and actors $(49 \%)$, and the lowest among commerce employees $(14 \%$ - hypermarket workers, $24 \%$ - retail employees), researchers from research institutes $(30 \%)$ and representatives of local administration $(31 \%)$. Due to reasons mentioned in the introduction it is extremely difficult to compare the above results to other studies conducted. The only similar research project pertains to financial elites in Poland [25], the results of which indicate that sport is practiced in free time 'relatively regularly' by $26 \%$ of respondents, hence a considerably smaller proportion than among the representatives of Warsaw socio-professional groups.

The study findings indicate that there are various models of practicing sport and leisure activities among particular sub-samples. The most active groups include pupils and students, nearly $19 \%$ and nearly $8 \%$ of whom respectively practice sport, while over $55 \%$ and $50 \%$ respectively involve in leisure. This is most definitely affected by compulsory physical education classes, as well as the activity of sport organizations at schools/universities or place of 
residence, as well as the influence from various environmental educational groups, e.g. family, school, or various formal and informal groups. Actors are the second most active group, $49 \%$ of whom declare to regularly involve in leisure, and nearly $6 \%$ - in organised sport. The interviews conducted among actors indicate that staying fit and preparation for roles performed were of key significance in the case of this professional group. They were followed by university teachers and civil servants. The rate of participation in organised sport was not too high in these groups ( $2 \%$ among teachers and $<1 \%$ among civil servants), nevertheless, regular involvement in leisure was declared by a considerably higher proportion of respondents (nearly 50\% and over $40 \%$ respectively). It seems that organised sport is too time and effort-consuming for civil servants and teachers, yet they clearly appreciate the significance of leisure physical activity in modern life. Unfortunately, far lower interest in physical activity can be observed among representatives of local administration, research institutes, as well as administrative and technical staff (at universities, hospitals, research institutes, and theatres). The proportion of individuals practicing organised sport exceeded $1 \%$, and those regularly involved in sport leisure amounted to ca. $30 \%$. Even though in the case of administrative and technical staff, for whom physical activity is a part of their professional work, this fact is not particularly intriguing, it might come as a surprise for the remaining groups, whose lifestyle is sedentary. The lowest proportion of individuals participating in sport and leisure was observed among commerce employees ( $2 \%$ and 19\% respectively), as well as healthcare professionals ( $6 \%$ and $27 \%$ respectively). The fact that only $27 \%$ of healthcare professionals exercise regularly does not sound too optimistic. It seems that especially the representatives of this profession should create the need for and shape proper habits related to active lifestyle.

The analysis of the above results indicates that sport activity among Warsaw residents surveyed is similar or higher than it is according to studies and surveys devoted to this type of activity in the Polish society, quoted in this work. Nevertheless, in the case of both organised sport and leisure it can be observed that the proportion of men practicing sport/leisure is higher than the proportion of women involved in this type of activity. Unfortunately, it also has to be stressed that physical activity is still below the recommended ACSM norms [26]. At the same time, the declarative character of opinions regarding physical activity is almost just as common as the tendency to avoid it in practical, regular action.

\section{Acknowledgements}

The research was financed by Ministry of Science and Higher Education project no Ds.-86-AWF and from the Rector of Warsaw School of Economics.

\section{Literature}

1. Cordeo-MacIntyre, Z., Peterson R., Fukuda D. \& Gungur S. (2006). Obesity a Worldwide Problem. New Horisons. 24th International Council for Physical Activity and Fitness Research Symposium, Wrocław.

2. Raitakari, O.T., Juoanala M., Kahonen M., Laitinen T., Maki-Torrko N., Jarvisalo M.J. \& et al. (2003). Cardiovascular risk factors in childhood and carotid artery intima-media thickness in adulthood. The cardiovascular risk in young Finns study. JAMA 290, 2277-2283.

3. Shengxu, L., Chen W., Srinivasan S.R., Bond M.G., Tang R., Urbina E.M. \& et al. (2003). Childhood cardiovascular risk factors and carotid vascular change in adulthood. The Bogalusa Heart Study. JAMA 5, 2271-2276.

4. Srinivasen, S.R., Myers L., Berenson G.S. (2002). Predictability of childhood adiposity and insulin for developing insulin resistance syndrome (syndrome $X$ ) in young adulthood. The Bogalusa Heart Study. Diabetes 51, 204-209.

5. Tremblay, M. \& Willms J. (2003). Is the Canadian childhood obesity epidemic related to physical inactivity? Int. J. Obes. 27, 1100-1105.

6. Trost, S.G., Sirard J.R., Dowda M., Pfeiffer K.A. \& Pate R.R. (2003). Physical activity in overweight and nonoverweight preschool children. Int. J. Obes. Relat. Metab. Disord. 27, 834-839.

7. US Department of Health and Human Services. (2001). The Surgeon General's Call to Action to Prevent and Decrease Overweight and Obesity (pp. 8-15). Rock-ville, MD: US Department of Health and Human Services. Public Health Services, Office of the Surgeon General.

8. Bottenburg, M. van, Rijnen B. \& et al. (2005) Sports participation in the European Union. Trends and differences. Arko Sports Media.

9. Krawczyk, Z. (2000). Sport in Changing Society. Warsaw: AWF Warszawa. [in Polish]

10. Mussino, A. (1999). Conceptual and operational problems in measuring participation in Sports, Bulletin 52nd Session of the International Statistical Institute, Helsinki,

http://www.stat.fi/isi99/proceedings/arkisto/varasto/mu ss0846.pdf 21.07.09 r.

11. http://www.stat.gov.pl/gus/definicje_PLK_HTML.htm 15.07.09 r. Definitions used in public statistics. GUS. [in Polish]

12. Gratton, C. (Ed.) (1999). COMPASS 1999. UK Sports Council, British Sports Council, Italian National Olympic Committee.

13. Sport and Physical Activity, Special Eurobarometer 72.3, European Commission, 2010

(http://ec.europa.eu/public_opinion/archives/ebs/ebs_33 4_en.pdf; 18.05.2010).

14. Drygas, W., Bielecki W. \& Puška P. (2002). Evaluation of physical activity of population of six European coun- 
tries. Project “Bridging East - West Health Gap". Polish J. Sports Med. 18(5), 169-174. [in Polish]

15. Słaby, T. (Ed.) (2006). Consumption of Financial Elites in Poland - Empirical Interpretation. Warsaw: SGH. [in Polish]

16. Sztompka, P. (2002). Sociology. Kraków: Znak. [in Polish]

17. Szczeklik, A. (2005). Inner Diseases. Kraków: Medycyna Praktyczna, Volume I, II. [in Polish]

18. Cole, T.J., Bellizzi M.C., Flegal K.M. \& Dietz W.H. (2000). Establishing a standard definition for child overweight and obesity worldwide: international survey. BMJ 320, 1240-1243.

19. Sokal, R.R \& Rohlf F.J. (1998). Biometry (3rd ed.). New York: W. H. Freeman.

20. Bywalec, C. (1998). Sport in budges of Polish families. In J. Lipiec (Ed.), Logos and Ethos of Polish Olimpizm. Kraków: AWF, Kraków. [in Polish]

21. Charzewski, J. (1997). Sports Activity of Poles. Warsaw: COS. [in Polish]

22. Gajewski, A.K., Biernat E. \& Jasionek A. (2004). Sports activity, recreation and tourism of Warsaw police officers from Judicial Police. Roczniki Naukowe AWF Warszawa 43, 36-45. [in Polish]

23. Radzińska, M. (2000). Different forms of recreational activity in education process vs. own free time behav- iours of physical education teachers. In I. KiełbasiewiczDrozdowska, M. Marcinkowski \& W. Siwiński (Eds.), Interdisciplinary issues of recreational, sports and tourism activity of the end of the 20 th century (pp. 128-133). Poznan: Polskie Stowarzyszenie Naukowe Animacji Rekreacji i Turystyki. [in Polish]

24. Salita, J. (2000). Women participation in physical recreation. In I. Kiełbasiewicz-Drozdowska, M. Marcinkowski \& W. Siwiński (Eds.), Recreational, sports and tourist activity in different social and professional environments. Diagnosis and suggestions of solution (pp. 261-266). Poznań: Polskie Stowarzyszenie Naukowe Animacji Rekreacji i Turystyki. [in Polish]

25. Alejziak, W. (2000). Tourist activity of financial elites in Poland. (preliminary research report). In J.

Wyrzykowski (Ed.), Studies over Free Time of Inhabitants of Big Polish Cities and its Use on Physical Recreation and Tourism (pp. 33-47). Wrocław: AWF Wrocław. [in Polish]

26. Craig, C.L., Marshall A.L., Sjostrom M. \& et. al. (2003). International physical activity questionnaire: 12 country reliability and validity. Med. Sci. Sports Exerc. 35, 13811395.

Submitted: July 1, 2010

Accepted: January 4, 2011 